\title{
Influence of Process Conditions on Drying by Atomization Pulp Umbu
}

Jackelinne de A Silva ${ }^{1}$, Maria IS Maciel ${ }^{1 \star}$, Naíra P de Moura ${ }^{1}$, Marcony E da S Júnior ${ }^{1}$, Janaína V de Melo², Patrícia M Azoubel ${ }^{3}$ and Enayde de A Melo ${ }^{1}$

${ }^{1}$ Federal Rural University of Pernambuco, Dois Irmãos, 52171-900, Recife, Brazil

${ }^{2}$ Center of Strategic Technologies of the Northeast, Cidade Universitária, 50740-540, Recife, Brazil

${ }^{3}$ Federal University of Pernambuco, Cidade Universitária, 50740-521, Recife, Brazil

\begin{abstract}
The present study evaluated the influence of variables involved in the drying process by atomization on the physico-chemical properties of umbu powder. The process was carried out using a laboratory scale atomizer with DE 15 maltodextrin as the carrier agent. Seventeen assays were performed according to a central composite rotational design. The independent variables were drying air temperature, mass feeding flow, and carrier agent concentration. The analyzed responses were water activity, moisture, hygroscopicity, process yield, and retention of phenolic compounds (RPC) in the final product. Drying air temperature negatively affected water activity and moisture content, i.e., higher applied temperatures led to lower water activity and moisture content in atomized umbu. However, the effects of the linear, quadratic, and interaction factors were not statistically significant over hygroscopicity and process yield at $95 \%$ level of statistical significance; therefore, it was not possible to generate a model. The RPC was influenced by the mass feeding flow and carrier agent concentration; the use of faster flows and higher concentrations of maltodextrin presented a final product with higher RPC. Based on the analysis of response surface graphs, an assay was selected and physically characterized: apparent density of $0.61 \mathrm{~g} / \mathrm{mL}$ and percentage of solubility of $80.28 \%$. Atomized umbu particles showed uniform size and formed numerous small pellets with spherical shape and predominantly rough surface.
\end{abstract}

Keywords: Dehydration; Experimental planning; Maltodextrin; Microstructure

\section{Introduction}

Atomization is a widely used technique by the food industry and consists in the transformation of liquid products to powdered products through exposure of the product to a current of hot air under high pressure. This type of drying process is usually used to ensure microbiological stability of products and avoid risk of biological degradation while reducing storage and transportation costs [1].

This process has been used in the production of fruit powder and reported in a series of studies [2-5] the goals of which were to establish the best drying conditions by optimizing and adapting the conditions to each type of fruit. Atomization drying represents an attractive alternative in the case of umbu because its consumption in natura is limited to the production region due to its high perishability.

In general, powdered fruits present many advantages and economic potentials over fruit in natura, such as reduced volume and/or weight, reduced packaging, easier transport and storage, and increased shelf life. However, the atomization of products with low molecular weights and high sugar content, such as fruits, presents problems of deposition and adhesion of particles, reducing the process yield $[6,7]$.

Nevertheless, these problems can be minimized with the use of carrier agent additives. These agents are applied before the product is atomized and are responsible for the micro-encapsulation that protects sensitive constituents, such as pigments, compounds responsible for flavor and aroma, and bioactive compounds, such as phenolic compounds.

The physico-chemical properties of food powders obtained by atomization depend on variables such as the characteristics of the feeding liquid and drying air, atomizer type, and operating mechanism. Thus, optimization of the process is important in order to obtain products with improved nutritional and sensory characteristics and optimized yield [3].
Hence, the study of the atomizing process effects on the characteristics of powdered umbu is important because this product is an ingredient in processed foods and drying ensures its availability in times of scarcity. This study evaluated the effect of the drying temperature, mass feeding flow, and maltodextrin concentration on responses related to water activity, moisture, hygroscopicity, yield, and phenolic compounds contents in atomized umbu pulp.

\section{Material and Methods}

\section{Materials}

Umbu fruits were acquired from the Supply and Logistics Center of Pernambuco (Pernambuco, Brazil). Semi-ripe and ripe fruits were selected, washed in running water, sanitized, and pulped. Pulp was stored frozen $\left(-22^{\circ} \mathrm{C}\right)$ in polyethylene bags. The pulp was thawed as needed prior to the atomizing process. Table 1 shows the physicochemical and colorimetric composition of umbu pulp in natura.

Maltodextrin MOR-REX 1914 (Corn Products, Mogi-Guaçu, Brazil) with DE 15 was used as the carrier agent.

\section{Preparation of samples}

The pulp was sifted to eliminate particles whose diameter was greater than the diameter of the atomizer nozzle to facilitate passage. Maltodextrin at concentrations calculated on the basis of the weight of

*Corresponding author: Maria IS Maciel, Federal Rural University of Pernambuco, Dois Irmãos, 52171-900, Recife, Brazil Tel: 55-81-33206536; E-mail:m.ines@dcd.ufrpe.br

Received May 01, 2014; Accepted June 13, 2014; Published June 20, 2014

Citation: de A Silva J, Maciel MIS, de Moura NP, da S Júnior ME, de Melo JV, et al. (2014) Influence of Process Conditions on Drying by Atomization Pulp Umbu. J Bioprocess Biotech 4: 163 doi: 10.4172/2155-9821.1000163

Copyright: (C) 2014 de A Silva J, et al. This is an open-access article distributed under the terms of the Creative Commons Attribution License, which permits unrestricted use, distribution, and reproduction in any medium, provided the original author and source are credited. 


\begin{tabular}{|l|c|c|}
\hline Component & Average value & Method of analysis \\
\hline Water activity & $0.98 \pm 0.00$ & water activity analyzer \\
\hline Humidity (\%) & $86.65 \pm 0.25$ & moisture titrator \\
\hline Soluble solids ( ${ }^{\circ}$ Brix) & $10.00 \pm 1.00$ & refractometer \\
\hline Titratable acidity (g citric acid) & $3.05 \pm 0.12$ & AOAC (2006) \\
\hline pH & $2.00 \pm 0.05$ & pH meter \\
\hline Proteins (\%) & $0.84 \pm 0.34$ & AOAC (1990) \\
\hline Lipids (\%) & $0.34 \pm 0.01$ & Bligh and Dyer (1959) \\
\hline Carbohydrates (\%) & $11.68 \pm 0.27$ & difference \\
\hline Phenolic compounds (mg/100 g) & $158.78 \pm 8.47$ & Wettasinghe and Shahidi (1999) \\
\hline Ashes & $0.49 \pm 0.13$ & AOAC (1990) \\
\hline Color & & McGuire (1992) \\
\hline L $^{*}$ & $63.89 \pm 5.01$ & \\
\hline a $^{*}$ & $-4.92 \pm 0.58$ & \\
\hline $\mathrm{b}^{*}$ & $38.25 \pm 3.77$ & \\
\hline
\end{tabular}

Table 1: Physico-chemical and colorimetric composition of umbu pulp in natura

the sieved pulp was added to the stirred pulp until complete dissolution. Water (approximately $50 \% \mathrm{v} / \mathrm{v}$ ) was added before the solution entered the atomizer.

\section{Spray drying}

Spray drying process was performed in a laboratory scale spray dryer Labmaq model MSD 1.0 (Ribeirao Preto/SP, Brazil), with a $1.2 \mathrm{~mm}$ diameter nozzle. The mixture was fed into the chamber by a peristaltic pump, drying flow rate was $30 \mathrm{~m}^{3} / \mathrm{h}$ air flows and compressor air pressure was 0.6 bar.

A rotatable central composite design was used to perform the tests for the microencapsulation of umbu pulp, considering three factors (independent variables): inlet air temperature $\left(90-190^{\circ} \mathrm{C}\right)$, feed flow rate $(0.2-1.0 \mathrm{~L} / \mathrm{h})$ and carrier agent concentration $(10-30 \%, \mathrm{w} / \mathrm{w})$. Five levels of each variable were chosen for the trials, including the central point and two axial points, giving a total of 17 combinations (Table 2). The responses (dependent variables) were: moisture content, water activity, hygroscopicity, phenolic compounds content and yield. Process yield was calculated as the ratio between the total solids content in atomized umbu and total solids content in the mixture.

The following polynomial equation was fitted to the data:

$$
y=\beta_{0}+\beta_{1} x_{1}+\beta_{2} x_{2}+\beta_{3} x_{3}+\beta_{11} x_{1}^{2}+\beta_{22} x_{2}^{2}+\beta_{33} x_{3}^{2}+\beta_{12} x_{1} x_{2}+\beta_{13} x_{1} x_{3}
$$
$+\beta_{23} x_{2} x_{3}$ (Equation 1)

Where $\beta_{\mathrm{o}}$ are constant regressions coefficients; $\mathrm{y}$ is the response (moisture content, water activity, hygroscopicity, RPC and yield) and $\mathrm{x}_{1}, \mathrm{x}_{2}$ and $\mathrm{x}_{3}$ are the coded independent variables (inlet air temperature, feed flow rate and carrier agent concentration, respectively).

The analysis of variance (ANOVA), test of lack of fit ( $F$ test), determination of regression coefficients, and the generation of response surfaces were carried out using Statistica 7.0 software (Stat Soft, Tulsa, USA).

\section{Analytical methods}

Atomized umbu was analyzed for moisture content, water activity, hygroscopicity, and phenolic compounds. Moreover, the assay that presented the best drying conditions selected from the graphs of surface response was physically characterized (apparent density, solubility, and morphology). Analyses were performed in triplicate and according to the procedures described below.
Water activity: A water activity analyzer (Aqualab model 4TE) was used to determine water activity at $25^{\circ} \mathrm{C}$.

Moisture content: Moisture content was determined over the course of thirty minutes at $105^{\circ} \mathrm{C}$ using the Marte apparatus model IDSO. The results were expressed as percentage of moisture.

Hygroscopicity: Hygroscopicity was determined according to the modified methodology proposed by Cai and Corke [8]. Samples of approximately $1 \mathrm{~g}$ were placed in a hermetically sealed container containing a $\mathrm{NaCl}$ saturated solution (relative humidity $75.29 \%$ ) at $25^{\circ} \mathrm{C}$; these samples were weighed after one week, and the hygroscopicity was expressed as $\mathrm{g}$ of adsorbed moisture per $100 \mathrm{~g}$ of dry mass sample $(\mathrm{g} / 100 \mathrm{~g})$.

Phenolic compounds: Phenolic compounds were extracted with acetone according to the procedure described by Singleton et al. [9] Total phenolic compounds content was measured with the FolinCiocalteau reagent (Merck) and determined by interpolating sample absorbance against a gallic acid calibration curve, according to the methodology described by Wettasinghe and Shahidi [10]. The results were converted to RPC terms using the dry mass (m.s.) of umbu pulp. Maltodextrin concentration was not used in the calculation.

\section{Physical characterization of atomized umbu:}

Apparent density: The apparent density $\left(\rho_{b}\right)$ was measured following the procedure described in previous studies with modifications $[11,12]$. Approximately $2 \mathrm{~g}$ of atomized umbu was transferred to a $10 \mathrm{~mL}$ measuring cylinder. The powder was compressed by hitting the measuring cylinder on the bench for about 50 times. The $\rho_{(b)}$ was calculated by dividing the powder mass by the volume occupied on the measuring cylinder.

Solubility: Solubility was measured according to the methodology described by Cano-Chauca et al. [13].

Particle morphology: Particle morphology was determined by Scanning Electron Microscopy (SEM) in the Laboratory of Electron Microscopy and Microanalysis (Center of Strategic Technologies of the Northeast - CETENE). The samples were fixed in metallic containers for specimens (stubs) with a conventional conductive double-sided adhesive tape. Subsequently, samples were gold metalized at the covering

\begin{tabular}{|c|c|c|c|}
\hline Assay & ${\text { Temperature }\left({ }^{\circ} \mathrm{C}\right)}^{\text {Mass flow rate }(\mathrm{l} / \mathrm{h})}$ & Carrier agent $(\%)$ \\
\hline 01 & $-1(110)$ & $-1(0.36)$ & $-1(14)$ \\
\hline 02 & $+1(170)$ & $-1(0.36)$ & $-1(14)$ \\
\hline 03 & $-1(110)$ & $+1(0.84)$ & $-1(14)$ \\
\hline 04 & $+1(170)$ & $+1(0.84)$ & $-1(14)$ \\
\hline 05 & $-1(110)$ & $-1(0.36)$ & $+1(26)$ \\
\hline 06 & $+1(170)$ & $-1(0.36)$ & $+1(26)$ \\
\hline 07 & $-1(110)$ & $+1(0.84)$ & $+1(26)$ \\
\hline 08 & $+1(170)$ & $+1(0.84)$ & $+1(26)$ \\
\hline 09 & $0(140)$ & $0(0.60)$ & $0(20)$ \\
\hline 10 & $0(140)$ & $0(0.60)$ & $0(20)$ \\
\hline 11 & $0(140)$ & $0(0.60)$ & $0(20)$ \\
\hline 12 & $-1.68(90)$ & $0(0.60)$ & $0(20)$ \\
\hline 13 & $+1.68(190)$ & $0(0.60)$ & $0(20)$ \\
\hline 14 & $0(140)$ & $-1.68(0.20)$ & $0(20)$ \\
\hline 15 & $0(140)$ & $+1.68(1.00)$ & $0(20)$ \\
\hline 16 & $0(140)$ & $0(0.60)$ & $-1.68(10)$ \\
\hline 17 & $0(140)$ & $0(0.60)$ & $+1.68(30)$ \\
\hline & & &
\end{tabular}

Table 2: Experimental planning for drying by atomization. 


\begin{tabular}{|c|c|c|c|c|c|}
\hline Assay & $\begin{array}{c}\text { Water } \\
\text { activity }\end{array}$ & $\begin{array}{c}\text { Moisture } \\
\mathbf{( \% )}\end{array}$ & $\begin{array}{c}\text { Hygroscopicity } \\
\mathbf{( g / 1 0 0} \mathbf{g})\end{array}$ & $\begin{array}{c}\text { Yield } \\
\mathbf{( \% )}\end{array}$ & $\begin{array}{c}\text { Retention of } \\
\text { Phenolic Compounds (\%) }\end{array}$ \\
\hline 1 & 0.19 & 3.25 & 18.22 & 12.29 & 35.55 \\
\hline 2 & 0.13 & 2.36 & 17.07 & 12.18 & 33.33 \\
\hline 3 & 0.25 & 5.62 & 19.76 & 14.90 & 35.55 \\
\hline 4 & 0.10 & 2.38 & 16.89 & 20.49 & 33.33 \\
\hline 5 & 0.24 & 4.20 & 10.23 & 14.96 & 44.44 \\
\hline 6 & 0.09 & 2.01 & 12.98 & 11.79 & 40.00 \\
\hline 7 & 0.21 & 4.70 & 17.94 & 17.88 & 48.88 \\
\hline 8 & 0.17 & 3.86 & 13.67 & 08.88 & 60.00 \\
\hline 9 & 0.13 & 3.02 & 14.85 & 09.21 & 44.44 \\
\hline 10 & 0.12 & 3.89 & 13.85 & 10.07 & 44.44 \\
\hline 11 & 0.12 & 3.15 & 17.28 & 15.39 & 40.00 \\
\hline 12 & 0.25 & 5.59 & 15.42 & 09.85 & 33.33 \\
\hline 13 & 0.10 & 2.09 & 15.16 & 13.01 & 33.33 \\
\hline 14 & 0.11 & 2.34 & 19.44 & 15.98 & 57.77 \\
\hline 15 & 0.19 & 4.18 & 13.53 & 07.34 & 68.88 \\
\hline 16 & 0.11 & 4.35 & 14.77 & 14.79 & 28.88 \\
\hline 17 & 0.13 & 2.86 & 14.65 & 10.68 & 57.77 \\
\hline
\end{tabular}

Table 3: Water activity, moisture, process yield, hygroscopicity, and RPC in 17 assays based on the experimental planning.

\begin{tabular}{|c|c|c|c|c|c|}
\hline Coefficients & $\begin{array}{c}\text { Water } \\
\text { activity }\end{array}$ & Moisture & Hygroscopicity & Yield & $\begin{array}{c}\text { Retention } \\
\text { of phenolic } \\
\text { compounds }\end{array}$ \\
\hline$\beta_{0}$ & 0.15 & 3.52 & 15.63 & 12.92 & 43.52 \\
\hline$\beta_{1}$ & -0.09 & -1.91 & NS & NS & NS \\
\hline$\beta_{2}$ & 0.03 & 1.14 & NS & NS & -8.63 \\
\hline$\beta_{3}$ & NS & NS & NS & NS & 6.31 \\
\hline$\beta_{11}$ & 0.04 & NS & NS & NS & 15.25 \\
\hline$\beta_{22}$ & 0.02 & NS & NS & NS & 12.62 \\
\hline$\beta_{33}$ & NS & NS & NS & NS & NS \\
\hline$\beta_{12}$ & NS & NS & NS & NS & NS \\
\hline$\beta_{13}$ & NS & NS & NS & NS & NS \\
\hline$\beta_{23}$ & NS & NS & NS & NS & NS \\
\hline$R^{2}$ & 83.61 & 80.04 & 44.72 & 40.06 & 86.7 \\
\hline$F_{\text {cal }}$ & 15.78 & 28.07 & - & - & 17.44 \\
\hline
\end{tabular}

Table 4: Regression coefficients encoded for the second-order polynomial equation, $\mathrm{F}$ and $p$, and values of the coefficients of determination $\left(\mathrm{R}^{2}\right)$

rate of $10 \mathrm{~nm}$ thick, for 80 seconds, and $40 \mathrm{~mA}$ current. Samples were subsequently observed in a scanning electron microscope (FEI Quanta 200 FEG model, Netherlands) operating at $20 \mathrm{kV}$.

\section{Results and Discussion}

\section{Analysis of response surface}

Water activity, humidity, process yield, hygroscopicity, and RPC values are presented in Table 3 .

The regression coefficients for the second order polynomial equations are presented in Table 4. The obtained equation was tested for adequacy and fitness by Analysis of Variance (ANOVA). Table 5 summarizes the results.

Water activity (Aw): The analysis of variance for the model as fitted showed significance ( $p \leq 0.05$ ) and explained $83.61 \%$ of the variability in the water activity. Therefore, the model as fitted provides an approximation to the true system.

Figure 1 shows response surfaces generated through the proposed model, considering the central point of carrier agent concentration, mass flow rate, and drying air temperature.

The increase in drying air temperature, regardless of the mass feeding flow and carrier agent concentration, led to product Aw reduction (Figure 1). Thus, greater temperature gradient between the atomized product and drying air leads to higher heat transfer and, consequently, higher evaporation of water from the product resulting in lower Solval et al. [14] and Fazaeli et al. [15] used spray drying technology and observed a decrease in the particles Aw with increasing drying air temperature for melons and blackberries, respectively. However, the increase in mass feeding flow, independent of the carrier agent concentration used, led to increased product Aw values (Figure 1). Therefore, faster processes results in shorter contact time between the product and the drying air, making the process of heat transfer less efficient.

Moisture: The regression was significant and explained $80.04 \%$ of the variability $(\mathrm{p} \leq 0.05)$. According to Figure 2 , the drying air temperature was the variable that showed greater influence over the final moisture content of the particles; increasing this variable, independent of the mass feeding flow and concentration of the carrier agent values, there was a reduction in the product moisture content. Quek et al. [16] explained that in drying conditions with higher input temperatures, the heat transfer rate is increased and, consequently, particles with reduced moisture content are formed. Goula and Adamopoulos [4] also observed a decrease in particles moisture with increasing drying air temperature when using a new atomization technique in concentrated orange juice.

The moisture content in the obtained powders ranged from 2.01 to $5.62 \%$. Values within this range (3.81 and 5.39\%) are presented by Solval et al. [14]. The moisture content was significantly influenced by the drying air temperature and mass feeding flow.

The mass feeding flow in the mixture, presented in turn, a positive effect on moisture, i.e., the processes performed at higher mass feeding flows resulted in moister particles. However, when higher temperatures are used, the use of high mass feeding flow also resulted in powders with low moisture content, which confirmed that high temperature influences the drying process more than the mass feeding flow (Figure 2).

The results presented by Tonon et al. [3] when evaluating the influence of process conditions of spray drying on the physicochemical properties of açaí powder also indicated that the powders moisture content decreased with increasing drying air temperatures and decreasing mass feeding flow; the temperature effect was greater than that of mass feeding flow.

\begin{tabular}{|c|c|c|c|c|c|c|c|c|c|}
\hline \multirow{2}{*}{ Source } & \multicolumn{3}{|c|}{ Water activity } & \multicolumn{3}{c|}{ Moisture } & \multicolumn{3}{c|}{ RPC $^{*}$} \\
\cline { 2 - 11 } & DF & MS & F & DF & MS & F & DF & MS & F \\
\hline Regression & 4 & 0.01 & 15.78 & 2 & 8.47 & 28.07 & 4 & 412.46 & 17.44 \\
\hline Residual & 12 & 0.00 & & 14 & 0.30 & & 12 & 23.64 & \\
\hline Lack of fit & 10 & 0.00 & & 12 & 0.31 & & 10 & 27.05 & \\
\hline Pure error & 2 & 0.00 & & 2 & 0.22 & & 2 & 6.57 & \\
\hline TOTAL & 16 & & & 16 & & & 16 & & \\
\hline R $^{2}$ & 0.83 & & & 0.80 & & & 0.86 & & \\
\hline
\end{tabular}

NS: Not significant

DF: degree of freedom

MS: mean square

*Significant at $5 \%$ leve

Table 5: Analysis of variance for water activity, moisture and retention of phenolic compounds (RPC) in regression models of sonication treatment. 

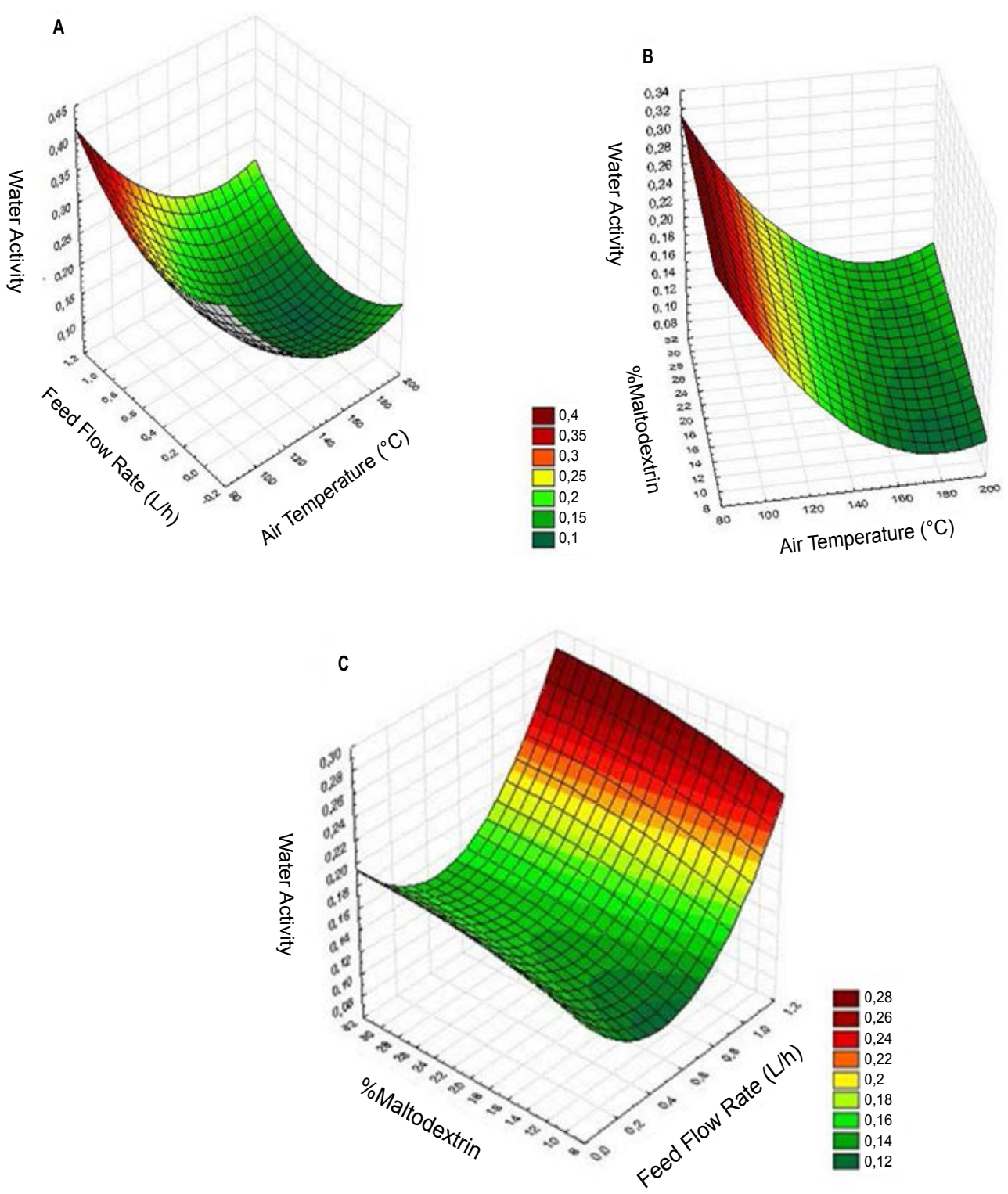

Figure 1: Response surface for water activity, (A) as a function of temperature $x$ mass feeding flow, (B) as a function of temperature $x$ carrier agent concentration, and $(\mathrm{C})$ as a function of mass feeding flow $\mathrm{x}$ carrier agent concentration.

Hygroscopicity: Results regarding the effects of processing conditions on powder hygroscopicity were not statistically significant. Thus, the response surface methodology was not applied to evaluate the experimental data.

According to Teunou_and Fitzpatrick [17], the adsorption of water by powdered food depends on the exposure time to high moisture conditions because water has to diffuse from the air into the food, resulting in greater powder cohesion and, consequently reducing the flow.

The hygroscopicity in atomized umbu ranged from 10.23 to $19.76 \mathrm{~g} / 100 \mathrm{~g}$ (Table 3). It decreased with increasing carrier agent concentration, due to the protection characteristic of the maltodextrin. This same behavior was observed by Moreira et al. [18], using different concentrations of maltodextrin in the spray drying acerola pulp.
The process yield: The yield of atomized umbu ranged from 7.34 to $20.49 \%$ (Table 3 ), which are considerably below the values obtained by most studies evaluating yield in spary drying processes $[3,15,19,20]$. According to Goula and Adamopoulos [21,22], the low yields in this type of process can be explained by the thermoplastic nature of sugar and low molecular weight organic acid molecules causing adhesion of particles on the drying chamber wall and the formation of unwanted clusters in the transmission systems. Retention and incomplete recovery of particles occurred during the process of atomization: particles remained adhered inside the atomizer, confirming the reports from those authors.

Retention of phenolic compounds: The analysis of variance for the model as fitted showed significance $(p \leq 0.05)$ and explained $86.70 \%$ of the variability in retention of phenolic content. 

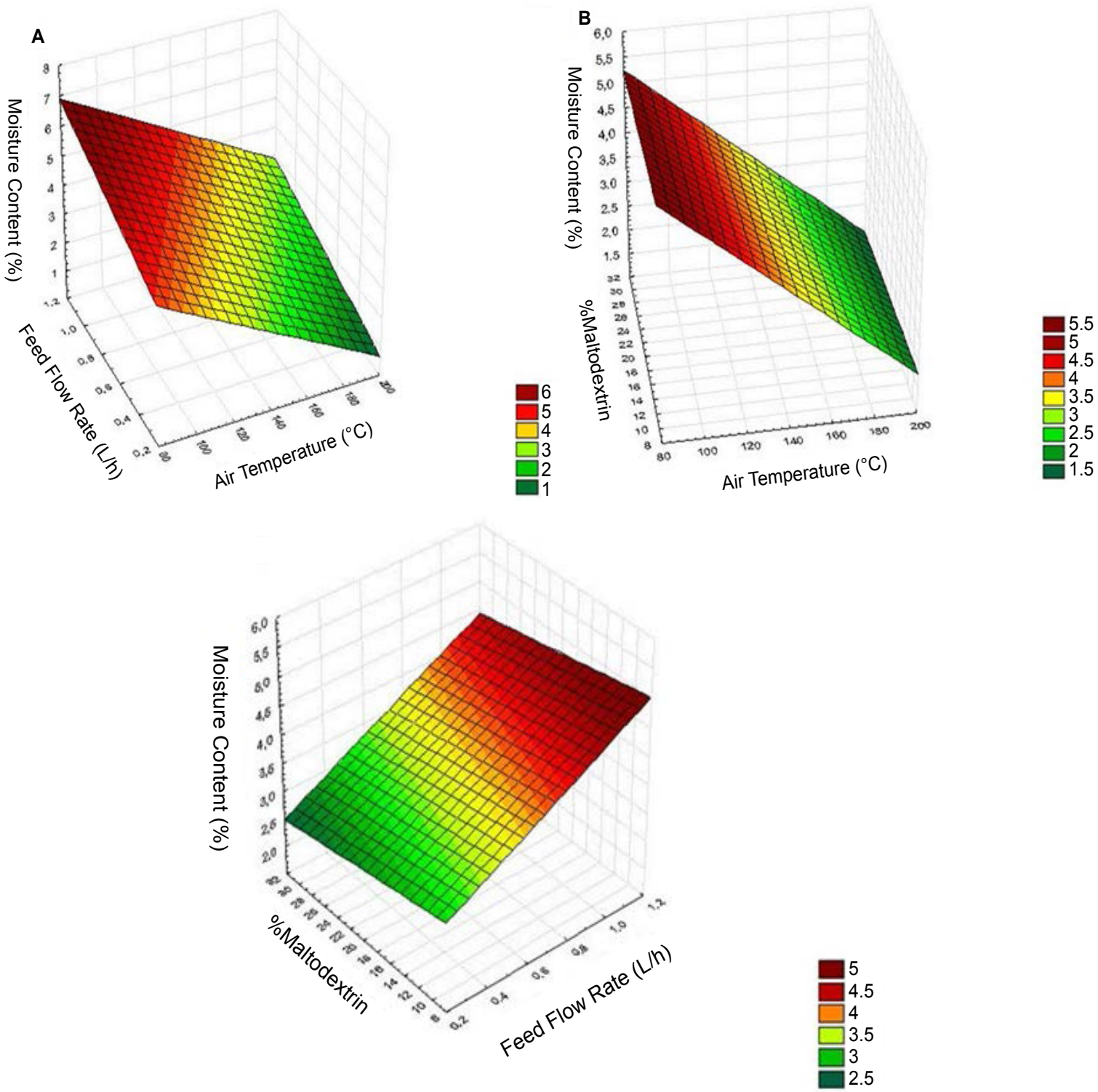

Figure 2: Response surface for moisture response, $(A)$ as a function of temperature $\times$ mass feeding flow, $(B)$ as a function of temperature $\times$ carrier agent concentration, and $(\mathrm{C})$ as a function of mass feeding flow $\times$ carrier agent concentration.

Figure 3 presents the response surfaces generated through the proposed model, considering the central points of carrier agent concentration, mixture mass feeding flow, and drying air temperatures. Umbu powders produced under maximum mass feeding flow showed higher rates of RPC regardless of the temperature used. However, the use of moderate to low flows, under high temperatures, resulted in significant losses of phenolic compounds, which could be explained by the fact that longer particles remained in the drying chamber leads, having greater exposure to elevated temperatures and, consequently, an increase in loss of heat-sensitive compounds.

In addition, particles produced at lower temperatures have a tendency to agglomerate [16]. This agglomeration causes the particles to have reduced exposed surface and uneven exposure to same environmental conditions, protecting compounds against degradation. This phenomenon could be responsible for the behavior shown in
Figure 3A, where increased retentions can be observed at moderate to low temperatures as a function of lower mass feeding flow.

The variable carrier agent concentration had the greatest influence on the RPC. Increased maltodextrin concentration led to higher RPC in atomized umbu. Such phenomenon is predictable because, according to Desai and Park [23], carrier agents are able to seal and hold active materials within their structures during processing or storing, thereby promoting maximum protection against environmental conditions.

The results showed that an increase in both mass feeding flow and carrier agent concentration led to smaller losses of phenolic compounds (Figure 3).

\section{Selection of the best drying condition}

Models predicting responses in water activity, moisture, and RPC were generated by determining coefficients of regression and ANOVA. 

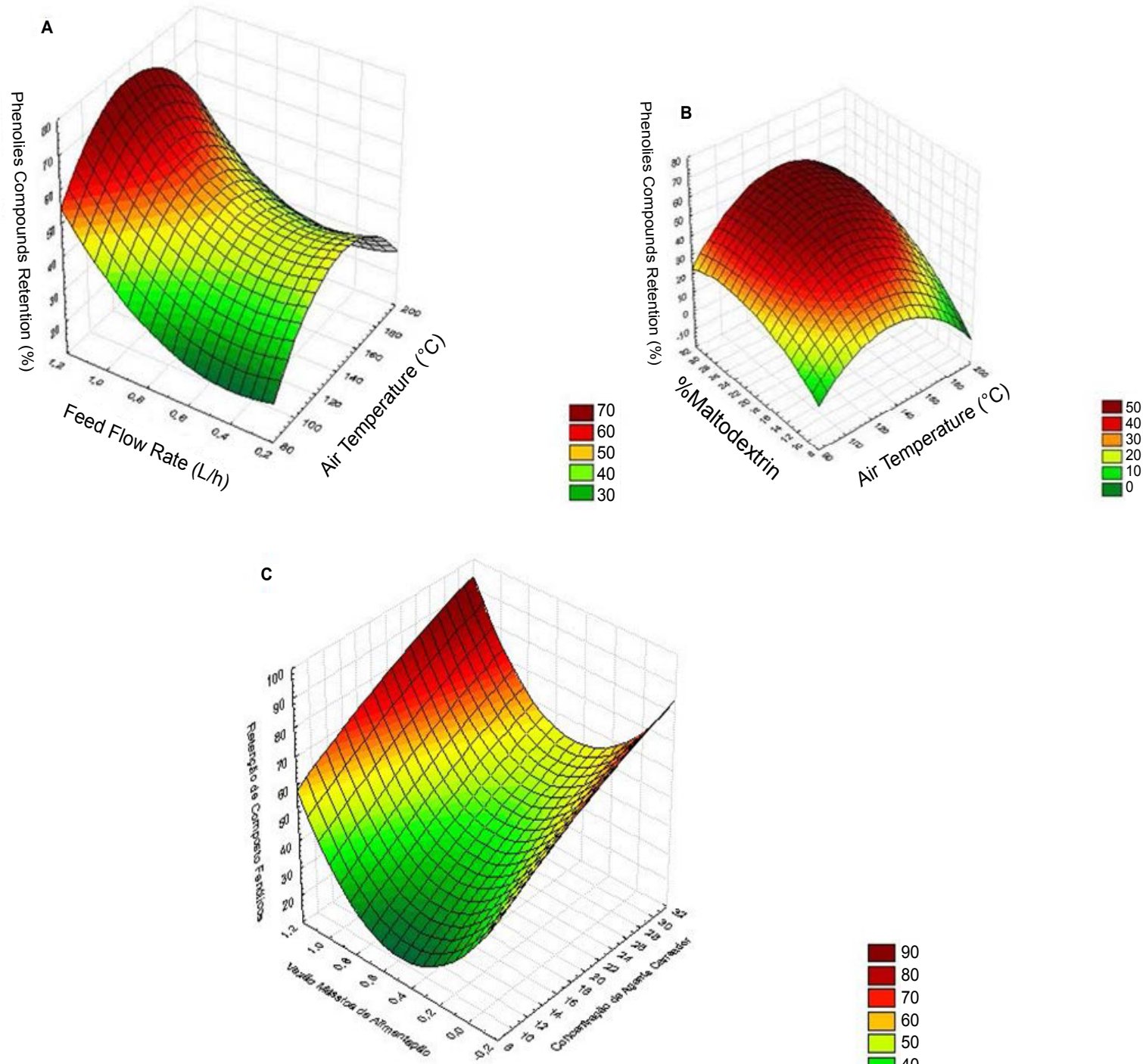

Figure 3: Response surface for the RPC, (A) as a function of temperature $\times$ mass feeding flow, (B) as a function of the carrier agent concentration $\mathrm{t} \times$ temperature, and $(C)$ as a function of mass feeding flow $\times$ carrier agent concentration.

The obtained models were not statistically significant for process yield and hygroscopicity responses. Additional studies are needed to optimize these properties in powdered umbu.

RPC was the main criterion used for the selection of the best drying condition because water activity and moisture content, determined in all samples, conferred chemical and microbiological stability to the product (Table 3); the hygroscopicity and process yield responses were not statistically significant.

The optimum set was chosen and an assay was performed at $133^{\circ} \mathrm{C}$ of air temperature, mass feeding flow of $0.91 \mathrm{~L} / \mathrm{h}$, and carrier agent concentration of $22 \%$.

\section{Validation of the obtained model}

The best drying condition which was explained in above (selection of the best drying condition) was used for the validation of the model

\begin{tabular}{|l|c|c|c|}
\hline \multicolumn{1}{|c|}{ Analysis } & Experimental Values & Predicted Values & DR\% \\
\hline Water activity & 0.14 & 0.16 & 9.13 \\
\hline Humidity (\%) & 5.51 & 5.58 & 1.25 \\
\hline RCF (\%) & 60.00 & 75.26 & 20.27 \\
\hline
\end{tabular}

$\mathrm{RD}=$ Relative Deviation, RFC = Retention of Phenolic Compounds

Table 6: Experimental and predicted values for the analyses performed on powder produced under selected conditions based on the response surface graphs.

obtained from the experimental design. The experimental results and predicted values are presented in Table 6 .

The experimental results for water activity and moisture were consistent with those predicted by the obtained model and showed deviations less than $10 \%$. The RPC, however, showed a relatively higher deviation, indicating that the model's prediction ability for this response was not as efficient as the others. 
Citation: de A Silva J, Maciel MIS, de Moura NP, da S Júnior ME, de Melo JV, et al. (2014) Influence of Process Conditions on Drying by Atomization Pulp Umbu. J Bioprocess Biotech 4: 163 doi: 10.4172/2155-9821.1000163
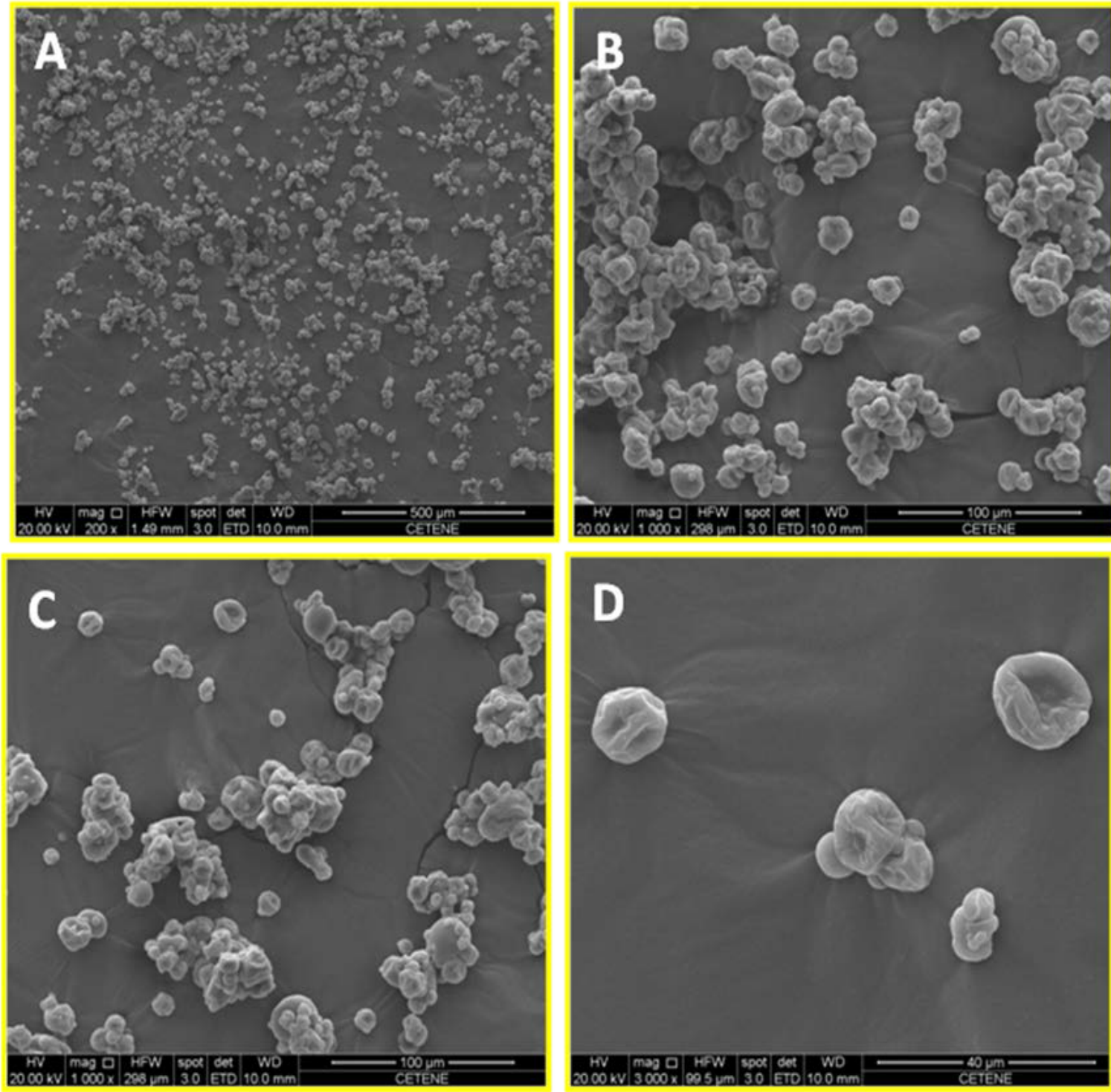

Figure 4: Electron Micrographs of umbu particles atomized at $133^{\circ} \mathrm{C}$. A - Overview of the distribution of particles; B - Presence of agglomerated particles; C - Minority presence of particles with smooth surface; and D - Detail of isolated particles with rough surface.

\section{Physical characterization of atomized umbu}

Apparent density and solubility: The apparent density of atomized umbu was $0.61 \mathrm{~g} / \mathrm{mL}$, which is similar to that presented by Abadio et al. [2] in a study with atomized pineapple, and is within the range presented by Caparino et al. [12], in a study with atomized mangoes (from 0.40 to $0.80 \mathrm{~g} / \mathrm{mL}$ ). However, smaller values of apparent density were presented by Tonon et al. [3] in a study with atomized açaí $(0.37$ to $0.48 \mathrm{~g} / \mathrm{mL}$ )

The volume of air present in powdered foods is inversely proportional to their density. Thus, according to Goula and Adamopoulos [24], a decrease in air volume causes an increase in apparent density. In addition, differences in drying conditions can influence the density of powdered food. Fazaeli et al. [15], for example, report density variations due to changes in drying temperature applied during atomization of blackberries.

The solubility of atomized umbu was $80.28 \%$, which is similar to data presented by Fazaeli et al. [15] and Abadio et al. [2]. The characteristics of the matter, drying conditions used, and type of carrier agent added to the atomized product directly influence the solubility of food powders. According to Cano-Chauca et al. [13], maltodextrin is widely used in the atomized drying processes because of its physical properties such as high solubility in water. Abadio et al. [2] reported that lower atomizing speeds were enough to obtain products with good solubility. Teunou and Fitzpatrick [17] and Goula and Adamopoulos [24] highlight that increased drying air temperature tends to increase the solubility of atomized food. According to Goula and Adamopoulos [21], these results from the effects that air temperature exerts on the residual moisture content in the powder; the lower the moisture content, the greater the solubility.

Particle Morphology: Particle surface analysis in atomized umbu was performed by scanning electron microscopy and the results are 
Citation: de A Silva J, Maciel MIS, de Moura NP, da S Júnior ME, de Melo JV, et al. (2014) Influence of Process Conditions on Drying by Atomization Pulp Umbu. J Bioprocess Biotech 4: 163 doi: 10.4172/2155-9821.1000163

presented in Figure 4.

According to Figure 4, atomized umbu particles showed uniform size (A) and formed small and numerous clusters (B) (Figure 4). Spherical shaped particles with predominantly rough surface, which is the characteristic morphology of food powders produced by the atomizing process, were observed; smooth surface was observed in the minority of the particles (C and D).

Similar results were obtained by Tonon et al. [3] in a study with atomized açaí, mainly when using $20 \%$ maltodextrin at $138^{\circ} \mathrm{C}$, conditions which are similar to those used in the present study. Alamilla-Beltrán et al. [25] observed that particles of maltodextrin produced under higher drying temperatures $\left(170-200^{\circ} \mathrm{C}\right)$ presented a spherical and smooth surface format, while particles produced under lower temperature $\left(110^{\circ} \mathrm{C}\right)$ presented a wrinkled appearance, similar to that of the atomized umbu particles produced at $133^{\circ} \mathrm{C}$. Nijdam and Langrish [26] explain that when the drying temperature is high enough, the moisture is rapidly evaporated with a subsequent formation of a dry and hard envelope, avoiding emptying the particle. However, when the drying temperature is low, the envelope remains moist and supple for longer periods, allowing the particle to deflate and wither during cooling.

As for agglomeration, the behavior of particles produced by atomization is closely related to the origin and concentration of the carrier agent used during the process. Cano-Chauca et al. [13] showed that the treatment of atomized mangoes with only $12 \%$ maltodextrin resulted in the formation of larger, agglomerated, and amorphous particles. Fazaeli et al. [15] observed similar results when using $8 \%$ of maltodextrin in the process of drying blackberries by atomization. In the present study, particles with lesser degree of agglomeration where obtained using $22 \%$ of maltodextrin. Therefore, the higher concentrations of maltodextrin used during atomizing processes in fruits tend to form less agglomerated particles [27-30].

\section{Conclusions}

The factorial planning applied in this study did not allow optimizing the drying process of umbu by atomization. However, the analysis of response surface graphs for the RPC proved that the development of atomized umbu is viable by applying the following drying conditions: air temperature of $133^{\circ} \mathrm{C}$, mass feeding flow of $0.91 \mathrm{~L} / \mathrm{h}$, and carrier agent concentration of $22 \%$. The obtained results show that there are good prospects for using the production of umbu pulp in the development of atomized fruit. This could expand the economic prospects of small producers and the diversification of products derived from umbu powder. Future studies could contribute to the further optimization of this process.

\section{Acknowledgments}

The authors are thankful to $\mathrm{CNPq}$ and Capes for the financial support.

This manuscript was reviewed by a professional science editor and a native English-speaking editor to improve readability.

\section{References}

1. Gharsallaoui A, Roudaut G, Chambin O, Voilley A, Saurel R (2007) Applications of spray-drying in microencapsulation of food ingredients: An overview. Food Research International 40: 1107-1121.

2. Abadio FDB, Domingues AM, Borges SV, Oliveira VM (2004) Physical properties of powdered pineapple (Ananáscomosus) juice - effect of malt dextrin concentration and atomization speed. Journal of Food Engineering 64: 285-287.

3. Tonon RV, Brabet C, Hubinger MD (2008) Influence of process conditions on the physicochemical properties of açai (Euterpeoleraceae Mart.) powder produced by spray drying. Journal of Food Engineering 88: 411-418.

4. Goula AM, Adamopoulos KG (2010) A new technique for spray drying orange juice concentrate. Innovative Food Science and Emerging Technologies 11 : 342-351.

5. Osorio C, Forero DP, Carriazo JG (2011) Characterization and performance assessment of guava (Psidiumguajava L.) microencapsulates obtained by spray-drying. Food Research International 44: 1174-1181.

6. Wang S, Langrish T (2009) A review of process simulations and the use of additives in spray drying. Food Research International 42: 13-25.

7. Turchiuli C, Gianfrancesco A, Palzer S, Dumoulin E (2011) Evolution of particle properties during spray drying in relation with stickiness and agglomeration control. Powder Technology 208: 433-440.

8. Cai YZ, Corke H (2000) Production and properties of spray-dried Amaranthus Betacyanin Pigments. Journal of Food Science 65: 1248-1252.

9. Singleton VI, Orthofer R, Lamucla-Reverentos RM (1999) Analysis of total phenol and other oxidation substrates and antioxidants by means of FolinCiocalteau. Methods in Enzymology 299: 152-178.

10. Wettasinghe M, Shahidi F (1999) Evening primrose meal: a source of natura antioxidants and scavenger of hydrogen peroxide and oxygen-derived free radicals. Journal Agriculture Food Chemistry 47: 1801-1812.

11. Barbosa-Cánovas GV, Juliano P (2005) Physical and chemical properties of food powders. In: Onwulata, C. (Ed.), Encapsulated and powdered foods.

12. Caparino OA, Tang J, Nindo Cl, Sablani SS, Powers JR, et al. (2012) Effect of drying methods on the physical properties and microstructures of mango (Philippine 'Carabao' var.) powder. Journal of Food Engineering 111: 135-148.

13. Cano-Chauca M, Stringheta PC, Ramos AM, Cal-Vidal J (2005) Effect of the carriers on the microstructure of mango powder obtained by spray drying and its functional characterization. Innovative Food Science \& Emerging Technologies 6: 420-428.

14. Solval KM, Sundararajan S, Alfaro L, Sathivel S (2012) Development of cantaloupe (Cucumismelo) juice powders using spray drying technology. LWT - Food Science and Technology 46: 287-293.

15. Fazaeli M, Emam-Djomeh Z, Ashtari AK, Omid M (2012) Effect of spray drying conditions and feed composition on the physical properties of black mulberry juice powder. Food and Bioproducts Processing 90: 667-675.

16. Quek SY, Chok NK, Swedlund P (2007) The physicochemical properties of spray-dried watermelon powders. Chemical Engineering and Processing 46: 386-392.

17. Teunou E, Fitzpatrick JJ (1999) Effect of relative humidity and temperature on food powder flowability. Journal of Food Engineering 42: 109-116.

18. Moreira GEG, Costa MGM, Souza ACR, Brito ES, Medeiros MFD, et al. (2009) Physical properties of spray dried acerola pomace extract as affected by temperature and drying AIDS. LWT - Food Science and Technology 42: 641 645

19. Maury M, Murphy K, Kumar S, Shi L, Lee G (2005) Effects of process variables on the powder yield of spray-dried trehalose on a laboratory spray-dryer. European Journal of Pharmaceutics and Biopharmaceutics 59: 565-573.

20. Gallo L, Llabot JM, Allemandi D, Bucalá V, Piña J (2011) Influence of spraydrying operating conditions on Rhamnuspurshiana (Cáscarasagrada) extract powder physical properties. Powder Technology 208: 205-214.

21. Goula AM, Adamopoulos KG (2005) Spray drying of tomato pulp in dehumidified air: I. The effect on product recovery. Journal of Food Engineering 66: 25-34

22. Goula AM, Adamopoulos KG (2006) Retention of ascorbic acid during drying of tomato halves and tomato pulp. Drying Technology 24: 57-64.

23. Desai KGH, Park HJ (2005) Recent developments in microencapsulation of food ingredients. Drying Technology 23: 1361-1394.

24. Goula AM, Adamopoulos KG (2008) Effect of Maltodextrin Addition during Spray Drying of Tomato Pulp in Dehumidified Air: II. Powder Properties. Drying Technology 26: 726-737

25. Allamilla-Beltrán L, Chanona-Pérez JJ, Jiménez-Aparicio AR, Gutiérrez-López GF (2005) Description of morphological changes of particles along spray drying. Journal of Food Engineering, 67: 179-184.

26. Nijdam JJ, Langrish TAG (2006) The effect of surface composition on the 
Citation: de A Silva J, Maciel MIS, de Moura NP, da S Júnior ME, de Melo JV, et al. (2014) Influence of Process Conditions on Drying by Atomization Pulp Umbu. J Bioprocess Biotech 4: 163 doi: 10.4172/2155-9821.1000163

Page 9 of 9

functional properties of milk powders. Journal of Food Engineering 77: 919925

27. Adhikari B, Howes T, Bhandari BR, Troung V (2004) Effect of addition of maltodextrin on drying kinetics and stickiness of sugar and acid-rich foods during convective drying: Experiments and modeling. Journal of Food Engineering 62: 53-68.

28. AOAC (2006) Official Methods of Analysis. $18^{\text {th }}$ edtn, Association of Officia Analytical Chemists, Gaithersburg, Maryland, USA
29. AOAC (1990) Official Methods of Analysis. $14^{\text {th }}$ edtn, Association of Official Analytical Chemists, Washington, DC, USA.

30. Barreto LS, Castro MS (2010) Boas práticas de manejo para o extrativismo sustentável do umbu, Embrapa Recursos Genéticos e Biotecnologia, Brasília. 